\title{
Kamppailu teollisuuskaupungin vedestä
}

\author{
Jarmo Kortelainen
}

Artikkelissa tarkastellaan veden merkitystä yhdyskunnalle Varkauden teollisuuskaupungin antaman esimerkin valossa. Lähestyn veden merkitystä yhdyskunnassa resurssien näkökulmasta. Käyttämäni resurssikäsite kattaa laajasti ne veden käyttötavat, jotka tuottavat käyttäjille erilaisia arvoja ja hyötyjä. Yhdyskuntien vettä on tarkasteltu yleensä teknisenä ja mekaanisena kysymyksenä. Yhdyskunta on nähty systeeminä, jonka yhtenä panoksena tarvitaan vettä ja jonka toiminnan tuloksena syntyy jätevettä. Tässä yhteydessä painotetaan vesistön yhteiskunnallista merkitystä, johon kuuluvat myös monet toiminnalliset ja symboliset resurssit. Vesi merkitsee yhdyskunnalle paljon muitakin resursseja kuin fyysisiä panoksia. Siihen liittyy myös sosiaalinen ja kulttuurinen ulottuvuus, sillä vesistöt ovat tärkeä osa paikallista elämäntapaa ja toimintaympäristöä. Vaikka kyseessä on yhden paikkakunnan tarkastelu, kertoo se paljon yleisemmästä vesien arvon ja merkityksen muutoksesta modernissa ja myöhäismodernissa yhteiskunnassa. Artikkeli perustuu yhdessä Hannu Itkosen kanssa tekemääni tutkimukseen (Itkonen \& Kortelainen 1998).

\section{Vesi tuotantoresurssina}

Varkaus on teollisuuskaupunki, joka on syntynyt ja kehittynyt metsä- ja metalliteollisuuden varassa. Tämä erityispiirre on hallinnut myös Varkauteen liittyviä mielikuvia, ja sitä on kutsuttu Ahlströmmin tai lyhyemmin Römmin kaupungiksi ja kolmen piipun kaupungiksi. Varkautta on luonnehdittu myös toiseen paikalliseen piirteeseen eli veteen viitaten vesien tai siltojen kaupungiksi. Nämä kaksi elementtiä - vesi ja teollisuus - ovat kytkeytyneet tiiviisti toisiinsa, minkä huomasi myös Hannu Soikkasen Varkauden historian avaussanoissaan:

"Luonnon antimet Varkaudelle ovat olleet suuret. Sijainti Saimaan vesistön painopisteessä on luonut edellytykset liikenteen, kaupan ja teollisen toiminnan kasvulle. Koskien voima taas on voitu valjastaa pyörittämään erilaisia rattaita. Näiden kahden perustekijän varaan onkin Varkauden kehitys nivoutunut." (Soikkanen 1963: 10.)

Paikallisten vesiresurssien tuotannollinen merkitys oli koko yhdyskunnan syntymisen perusta. Varkauden sijainti vesistöjen solmukohdassa toi paikkakunnalle metalliteollisuuden, joka viime vuosisadalla merkitsi laivanrakennusta ja konepajateollisuutta (Soikkanen 1963: 76-80). Erityisen tärkeä resurssi vesi on ollut metsäteollisuudelle, koska vesistöt tarjosivat puunjalostukselle runsaasti fyysisiä ja toiminnallisia resursseja. (Moilanen 1991: 42.) Koskivoima ja uittoreitit olivat tuotannon välttämättömiä edellytyksiä. Vesistöt tarjosivat myös edullisen keinon päästä 
eroon tehtaiden tuottamista jätevesistä. Tuotannon kasvu lisäsi jätevesipäästöjä. Jätevedet laskettiin käsittelemättöminä voimakanavan kautta pohjukkamaiseen Huruslahteen. Kaupungin keskellä ollut lahti saastui lähes käyttökelvottomaksi. Kuormitusta lisäsivät myös kauppalan jätevedet.

Tuotannollinen käyttö hallitsi veteen liitettyjä merkityksiä paikallisesti. Se ei ollut suinkaan ainoa resurssi, joka teki vedestä arvokkaan varkautelaisten näkökulmasta. Varkautelaiset saivat aina 1980-luvulle saakka käyttövetensä ympäröivistä vesistöistä, ja kalastus tarjosi tervetulleen lisän ruokapöytään. Muutenkin vesillä on virkistäydytty ja irrottauduttu teollisuuskaupungin arjen rutiineista kalastaen, veneillen tai kesämökkeillen.

Veden erilaisiin paikallisiin merkityksiin ja käyttötapoihin on liittynyt väistämättä monia ristiriitojen siemeniä. Varkauden asukkaat ovat hakeneet kalaa, puhdistautumista ja virkistystä samasta vedestä, jota teollisuus on käyttänyt jätteiden sijoituspaikkana. Vaikka tilanne johti ennen pitkää intressiristiriitoihin, ei Varkaudessa ole puhjennut vakavaa vesistökonfliktia missään vaiheessa. Artikkelin loppuosassa etsin vastauksia siihen, miksi paikalliset konfliktit jäivät leimahtamatta. Ja toiseksi tarkastelen sitä, ketkä lopulta vesiresursseista kamppailivat, jos varkautelaiset eivät nousseet kritisoimaan tehtaan aiheuttamaa vesien pilaantumista.

\section{Industrialistinen vesi}

Varkauden julkisen keskustelun kulttuuri heijastelee teollisuuspaikkakunnalle tyypillisiä paikallisen hallintatavan piirteitä.Tehdasyhdyskunnissa yhteiset asiat on hoidettu tavallisesti poliittisen järjestötoiminnan kautta. Vakiintuneet säännöt ja käytännöt määrittelevät sen, millä tavalla ja mitä kysymyksiä otetaan esille ja käsitellään kollektiivisesti. (Ks. Fortmann \& Kusel 1990; Konttinen 1994.) Metsäteollisuuden hallitsemille paikkakunnille on myös tyypillistä, että ne ovat valtarakenteeltaan ikään kuin metsäsektoriyhteiskuntia pienoiskoossa. Paikalliset metsäsektorieliitit (tehtaan johto, kaupungin johto ja työväenjärjestöt) ovat kyenneet varsin pitkään määrittelemään paikallisen kannan, joka on peittänyt alleen mahdolliset muut näkemykset.

Myös Varkaudessa yhteisiä asioita ajettiin työväenjärjestöjen kautta, ja yhtiöllä oli vahva rooli julkisen keskustelun suuntaajana ja säätelijänä. Tämän havaitsi myös Matti Kuusi, joka seurasi pitkään kaupungin tapahtumia lähistöllä sijainneelta kesäasunnoltaan. Hän kirjoittaa hieman provosoivasti seuraavaa:

"Varkaudessa sopii käyttää puheenvuoro viran puolesta. Varkaudessa sopii puhua toisten selän takana. Mutta kun olen seurannut paikallista äänenkannattajaa, olen saanut vaikutelman, että kaupungissa on epätavallisen paljon asioita, joista ei sovi julkisesti keskustella ja epätavallisen vähän yksityisiä kansalaisia, joilla on rohkeutta julkisesti keskustella yhteisistä asioista." (Kuusi 1965, 113-114.)

Kuusi ei erittellyt, mitä hän tarkoitti julkisesti keskustelemattomilla asioilla. Todennäköistä kuitenkin on, että ympäristöongelmat olivat yksi niistä. Paikallista asennoitumista ympäristöongelmiin on kuvattu termillä ympäristöorientaatio. Käsitteellä tarkoitetaan paikkakunnalla ympäristölle annettuja merkityksiä, joissa korostuvat yhteisön toiminnassa johtavan aseman saaneet tulkinnat. Niihin vaikuttavat yhteisön sosiaaliset rakenteet, historia ja nykyisyys sekä yhteiskunnassa laajemmin esiintyvät ympäristöä koskevat keskustelut. (Konttinen ja Litmanen 1996, 3 - 6.). Varkauden kohdalla voidaan puhua industrialistisesta ympäristöorientaatiosta, jossa vesi ja luonto yleensäkin ovat tuotannollisen resurssin merkityksessä. Saasteet ja muut haitat tuli nähdä välttämättömänä hintana, jotta hyvinvointia voitiin kasvattaa. Tämän saman ympäristötulkinnan jakoivat sekä yhtiön johto että työväenpuolueiden hallitsema paikallinen hallinto. 
Asukkaiden hiljaista sitoutumista industrialistiseen ympäristöorientaatioon voidaan selittää työpaikkariippuvuudella. "Sen lauluja laulat kenen leipää syöt" on usein toistettu vertaus. Selitys on kuitenkin varsin pinnallinen, eikä kerro syytä paikallisen ympäristökritiikin täydelliseen puuttumiseen. Esimerkiksi ammattiyhdistykset ovat kautta aikojen uskaltaneet esittää yhtiöitä kohtaan jyrkkääkin kritiikkiä ja painostaa niitä työolosuhteita koskeviin uudistuksiin (ks. Kortelainen 1996, 106). Myös vesikysymykset olisivat olleet potentiaalinen kohde vastaavanlaiselle kritiikille. Paikallista ympäristöprotestoinnin puutetta voidaan tulkita syvällisemmin teollisuustyöväestön sosiaalisia ja taloudellisia olosuhteita vasten.

Puute ja heikot elinolot olivat tuttuja teollistumisen alkuvaiheen sukupolven piirissä Varkaudessa. Esimerkiksi asumisolot olivat erityisen heikot suomalaisten tehdasyhdyskuntien joukossa 1900-luvun alkuvuosikymmeninä (ks. Schybergsson 1988). Tämä ei ollut kuitenkaan paikallinen eikä vain teollisuusyhdyskuntia koskenut ilmiö vaan puute ja niukkuus on liitetty koko aikakautta leimaavaksi kansalliseksi kokemukseksi (vrt. Roos 1987). Köyhä ja vasta itsenäistynyt Suomi alkoikin etsiä turvallisuutta ja taloudellista hyvinvointia teollisuuden kasvusta (ks. Konttinen 1996).

Tällaisessa paikallisessa ja kansallisessa tilanteessa oli ymmärrettävää, että työväenpuolueiden ja kaupungin johdon rooliksi Varkauden asukkaiden edun ajajina muotoutui taloudellisen ja sosiaalisen turvallisuuden edistäminen. Toimintatavat ja käsiteltävät asiat sementoituivat vähitellen pysyviksi käytännöiksi ja poliittisen toiminnan kulttuuriksi. Niitä oli vaikea muutta myöhemmin, vaikka hyvinvointi kasvoi ja ympäristöongelmat alkoivat häiritä yhä enemmän ihmisten jokapäiväistä elämää. Näin vesistöongelmatkin jäivät paikallisen poliittisen toiminnan ulkopuolelle.

Ei ole epäilystäkään siitä, etteivätkö vesistöjen pilaantumisongelmat puhuttaneet varkautelaisia. Ne eivät kuitenkaan juuri nousseet paikallisen politiikan tai julkisen keskustelun kysymyksiksi, koska niille ei ollut kanavaa. Työväenjärjestöt eivät sitä tarjonneet eikä myöskään A.Ahlström Oy:n omistama Warkauden Lehti. Tämä johti siihen, että teollisuus voi vapaasti määritellä sen, miten ja mihin tarkoituksiin vesistöjä käytti.

\section{Veden kilpailevat merkitykset}

Tilanne on muuttunut viime vuosikymmeninä. Teollisuuskaupungin perinteisen hallintatavan haastoivat uudet toimijat, jotka tulivat mukaan vesien merkitystä tuottaviin kamppailuihin. Kyse ei ollut mistään varsinaisesta ympäristökonfliktista, vaan nimenomaan määrittelykamppailusta. Varkauden vedet eivät olleet enää paikallinen yhtiön ja kaupungin sopima asia, vaan sitä alkoivat määritellä ja kontrolloida yhä enemmän kansallisen ja kansainvälisen tason toimijat.

Ensinnäkin kansalliset vesi- ja ympäristöviranomaiset alkoivat kiinnittää huomiota kansallisen vesi- ja ympäristöpolitiikan osana huomiota myös Varkauden vesien tilaan, joka oli yksi maan kehnoimmista. Näillä toimijoilla on myös ollut lainsäädännön antama toimivalta takanaan, mikä on pakottanut metsäteollisuusyhtiön noudattamaan asetettuja päästörajoja. Vesiviranomaisten vaikutus alkoi jo 1970-luvulla, kun kaupunki joutui rakentamaan jätevesien puhdistusjärjestelmänsä. Metsäteollisuuden päästökysymyksiin viranomaiset ottivat tiukemman kannan vasta 1990-luvulle tultaessa.

Toiseksi kaupunkiin perustettiin 1980-luvun lopulla lakisääteinen ympäristösihteerin virka, jonka haltija on toiminut eräänlaisena teollisuuden paikallisena kriitikkona. Hän nosti esille tehtaan aiheuttamia päästöjä ja ympäristöongelmia, jotka aiemmin oli pyritty pitämään salassa. Kun ympä- 
ristöpolitiikan ensimmäinen vaihe ulotti ulkopuolisten vesiviranomaisten vaikutuksen kaupunkiin, toivat 1980-luvun muutokset ympäristöviranomaisen fyysisesti paikkakunnalle. Varkaudessa kaupungin ympäristösuojelusihteerin tulolla on nähtävissä kaksi vaikutusta. Ensinnäkin hänestä tuli ainakin aluksi teollisuuden paikallinen ympäristökriitikko. Hänen luonnontieteellinen asiantuntemuksensa, lainsäädännön antama valtansa ja riippumattomuutensa paikallisesta poliittisesta perinteestä antoi mahdollisuuden esittää yhtiötä kohtaan kritiikkiä. Toiseksi paikallinen ympäristöviranomainen tarjosi virallisen vaikuttamiskanavan, jota asukkaat saattoivat käyttää ympärisöasioissa.

Kolmanneksi kansainväliset ja kansalliset ympäristöjärjestöt ovat olleet kiinnostuneita metsäteollisuusyhtiöiden vesistöpäästöistä ja tuoneet ne julkisuuteen erilaisten kampanjoidensa yhteydessä. Ympäristöjärjestöistä on tullut viime vuosikymmeninä merkittävä metsäteollisuuden toimintaan vaikuttava toimijaryhmä, joka on vaikuttanut paljon ympäristökysymysten saamaan julkisuuteen ja ympäristöpoliittisiin uudistuksiin myös vesikysymyksissä.Varkauden tehtaat ei ole joutunut ympäristöjärjestöjen kampanjoinnin kohteeksi, mutta esimerkiksi Greenpeace on tiedustellut Varkauden tehtaiden klooripäästöjä. Ympäristöjärjestöt ovat vaikuttaneet myös välillisesti Varkauden vesiin pyrkimällä vaikuttamaan paperimarkkinoiden asiakkaisiin ja ympäristöhallintoon.

Neljänneksi paperimarkkinoiden asiakkaat eli ulkomaiset tukkuliikkeet, painotalot ja kustantajat ovat alkaneet vaatia päästöjen hillitsemistä, mikä on suurelta osin ympäristöjärjestöjen kampanjoinnin tulosta. Koska ympäristöstä on tullut markkinatekijä, nähdään myös Varkauden tehtailla lupaehtojen alitus hyödylliseksi ja kannattavaksi toiminnaksi (ks. Enso Group 1997, 56). Pyrkimyksenä on vastata tuotteiden ostajien ja kuluttajien odotuksiin eli tavoitella kilpailuetua markkinoilla. Varkauden tehtaan ympäristösuojelupäällikkö totesikin haastattelussa, että asiakkaiden vaatimukset ovat tätä nykyä kovempia kuin viranomaisten asettamat normit. Asiakkaiden yhteydenotot ja tehtaiden ympäristöpäästöjä koskevat kyselyt ovat yleistyneet. Kiinnostuneita ollaan oltu Varkauden tehtaiden kuormitusluvista ja lupa-arvojen mahdollisista ylityksistä. Yrityksen myyntiedustajat tarkkailevat puolestaan asiakkaiden odotuksia Saksassa ja muualla ulkomailla. (Itkonen \& Kortelainen 1998.)

Kaikkien näiden toimijoiden Varkauden vesiä koskeneet määrittelypyrkimykset ovat olleet ristiriidassa paikkakunnalla aiemmin vallinneeseen industrialistiseen ympäristöorientaatioon nähden, jossa vesistön arvo määräytyi sen tuottaman taloudellisen ja tuotannollisen hyödyn kautta. Uusissa määritelmissä ovat korostuneet vesistön merkitys luonnonsuojelun, vapaa-ajan käytön ja ympäristön viihtyisyyden näkökulmasta. Käänteen merkit näkyivät myös paikallisessa ympäristöjulkisuudessa 1980-luvun puolivälistä lähtien. Tärkeä tekijä oli yhtiön paikallisen mediamonopolin murtuminen, kun Warkauden Lehti siirtyi Ahlströmiltä Savon Sanomien haltuun vuonna 1986 (Pitkänen 1998). Esimerkin muutoksesta antaa seuraava lainaus.

"Varsinainen ongelma vesistöille ovat Varkaus ja sen tehtaat. Enson päästämät jätteet aiheuttavat alapuolisissa vesissä rehevöitymistä ja happikatoa." (WL 5.7.1990.)

Tehtaan omistanut yhtiö muun metsäteollisuuden mukana pyrki aluksi vastustamaan vesiensuojelun tehostamistavoitteita vedoten suuriin taloudellisiin kustannuksiin. Sittemmin kun vaatimuksiin oli taivuttava, jouduttiin jätevesien käsittelyä tehostamaan Varkaudessakin. Tätä kautta metsäteollisuus

löysi vesistölle uudenlaisen taloudellinen resurssikäytön. Kun aiemmin yhtiöt hyödynsivät vesistöjä kuljetusreitteinä, energialähteinä ja edullisina viemäreinä, hyödynnetään sitä nykyisin myös 
ympäristönsuojelun symbolina luotaessa yrityksille ympäristöimagoja. Siitä on osoituksena esimerkiksi Enson asiakkailleen suuntaamassa ympäristöraportissa ollut kuva Saimaan norpasta ja sen yhteydessä ollut teksti:

"Kiitokset onnistuneesta ympäristönsuojelusta Varkauden tehtaille antoi Saimaan norppa, joka ilmestyi tehtaan rantaan 18.12.1996. Paikallislehti risti norpan Aapoksi.“ (Enso Group 1997, 57.)

Ympäristöimagoa ei voida enää rakentaa pelkkien symbolien varaan. Lukuisat asiantuntijajärjestelmät valvovat vesistöjen tilaa, eikä yhtiöllä ole varaa virheisiin. Epäonnistuminen vesiensuojelussa romuttaisi imagon rakentamispyrkimykset. Tämän vuoksi tehtaalla pyritään varmistamaan, ettei virheitä pääse tapahtumaan. Teknisten ratkaisujen kehittäminen on yhä ollut keskeisellä sijalla. 1990-luvulla on vähennetty jätevesiä prosessin sisäisin keinoin. Varkauden tehtailla on toteutettu prosessimuutoksia, jotka vähentävät tehtaan jätevesipäästöjä. (Enso Group 1997, 56.) Tällä tavalla yhtiö pyrkii takaamaan yhä edelleen puhdistuvan vesistön tarjoaman symbolisen resurssin saatavuuden myös tulevaisuudessa. (Itkonen \& Kortelainen 1998.)

\section{Johtopäätökset}

Vesi merkitsee yhdyskunnalle hyvin laajan kirjoa erilaisia resursseja. Veden tarjoamat resurssit on mahdollista jakaa fyysisiin, toiminnallisiin ja symbolisiin. Fyysisenä resurssina vesi tuottaa materiaalisia panoksia tai energiaa yhdyskunnan teollisuudelle ja kotitalouksille. Tähän ryhmään kuuluvat esimerkiksi käyttövesi, juomavesi, vesivoima ja kotitarvekalastus. Toiminnallisena resurssina vesi on lähellä edellä mainittua palvelumerkitystä. Vesistöt tarjoavat mahdollisuuksia kuljetukseen, jätteiden poistoon, vapaa-ajan viettoon ja virkistäytymiseen sekä muuhun yhdyskunnan elämänmenoon. Symbolisena resurssina vettä voidaan hyödyntää esimerkiksi markkinoitaessa paikkakuntaa tai luotaessa sille imagoa, ja siihen liittyy monia yksityisesti koettuja symbolisia merkityksiä (esim. maisema-arvot).

Taulukko 1. Vesistöjen Varkauden yhdyskunnalle tarjoamia resursseja

\begin{tabular}{|l|l|l|l|}
\hline VESIRESURSSIT & YHTIÖ & KAUPUNKI & KANSALAISET \\
\hline Fyysinen resurssi & $\begin{array}{l}\text { vesivoima } \\
\text { käyttövesi }\end{array}$ & vesihuolto & $\begin{array}{l}\text { kotitalousvesi } \\
\text { kalaravinto }\end{array}$ \\
\hline $\begin{array}{l}\text { Toiminnallinen } \\
\text { resurssi }\end{array}$ & $\begin{array}{l}\text { kuljetukset } \\
\text { jätehuolto }\end{array}$ & $\begin{array}{l}\text { vapaa-ajan palvelut } \\
\text { jätehuolto }\end{array}$ & $\begin{array}{l}\text { liikkuminen } \\
\text { virkistäytyminen } \\
\text { jätehuolto }\end{array}$ \\
\hline Symbolinen resurssi & ympäristö-imago & kaupunki-imago & $\begin{array}{l}\text { identiteetti } \\
\text { maisema-arvot }\end{array}$ \\
\hline
\end{tabular}

Viime vuosikymmeninä veden merkitys Varkauden yhdyskunnalle on kokenut muutoksen. Teollistumisen alkuajoista aina 1970-luvulle saakka veden merkitys määräytyi pitkälle tuotannollisen hyödyntämisen kautta. Veden käyttöä voitiin pitkälti säädellä paikallisesti, ja teollisuuskaupungille tyypilliset poliittisen toiminnan käytännöt ja perinne antoivat hyvinvointia tuottavalle tehtaalle vapaat kädet. Sittemmin tehtaan vapaan vesien käytön kyseenalaistivat sellaiset ulkopuoliset toimijat kuten ympäristöviranomaiset, ympäristöliikkeet ja paperiteollisuuden asiakkaat. Samalla myös saivat uutta painoarvoa veden merkitykset, joissa korostuivat luonnonsuoje- 
lu, virkistyskäyttö ja asuinympäristön laatu. Toimijoiden panos pakotti vesien suojelun tehostamiseen myös Varkauden tehtailla, mikä johti lähivesien tilan paranemiseen.

Viime aikoina julkisuudessa on puhuttu paljon vesistöjen puhdistumisesta. Kunniaa on annettu metsäteollisuudelle ja painotettu, että juuri paperi- ja sellutehtaiden ympäristöinvestoinnit ovat puhdistaneet vesistöt. Muiden vastaavien ohella Varkaudenkin esimerkki osoittaa, että kyse on kuitenkin laajemmasta kysymyksestä ja useista eri toimijoista. Metsäteollisuudella on omat merkittävät ansionsa ja tulokset sinällään ovat hyviä, mutta sen ansioksi vesien puhdistumista ei voida lukea. Sysäys ei tullut metsäteollisuuden sisältä vaan muilta toimijoilta. Metsäteollisuus pikemminkin vastusti kustannussyihin vedoten vesien suojelun tehostamista niin pitkään kuin mahdollista, ja vasta viranomaisten asettamien pakkojen, lukuisien vesistökonfliktien ja asiakkaiden vaatimusten jälkeen vesien suojelun tehostamiseen alettiin panostaa tosissaan.

Metsäteollisuudelle annetut kehut ja vesien suojelussa onnistuminen on nostanut näkyville itsesääntelypyrkimyksiä. Varkauden tehtaillakin tavoitteeksi on otettu viranomaisten luparajojen alle pääseminen. Pyrkimystä voidaan tulkita niin, että siinä yritetään siirtää määrittelyvaltaa ympäristöviranomaisilta yhtiöille. Metsäteollisuus pyrkii näin osoittamaan kykenevänsä ja olevansa halukas tekemään enemmän kuin ympäristöviranomaiset vaativat. Teollisuusjohtajien mukaan ympäristöpolitiikalla on ollut vain alkusysäyksen antajan rooli, kunnes teollisuus alkaa oma-aloitteisesti vähentää päästöjään. Määräävässä asemassa nähdään olevan teknologian ja sen kehityksen, jotka sanelevat vesien suojelun mahdollisuudet. Vesiensuojelu ei ole kuitenkaan pelkkä teknologinen kysymys. Puhdistustekniikkaa ei olisi kehitetty ja otettu käyttöön ilman tiukkoja säännöksiä ja kriittisten toimijaryhmien painostusta. Tämän vuoksi veden merkityksen määrittelyvaltaa ei ole syytä antaa vastakaan teollisuuden yksinoikeudeksi.

\section{Lähteet}

Enso Group (1997). We all need paper. Ympäristövuosi 1996. Enso Oy, Helsinki.

Fortmann, L. \& J. Kusel (1990). New Voices, Old Beliefs: Forest Environmentalism Among New and Long-Standing Rural Residents. Rural Sociology 55:2, 214-232.

Itkonen, Hannu \& Jarmo Kortelainen (1998). Tutkimusnäytteitä yhdyskunnan vesiresursseista. Alue ja Ympäristö 27:1, 79-93.

Konttinen, Esa (1996). Ympäristön muodostuminen yhteiskunnalliseksi kysymykseksi 1980-luvun taitteen murroksessa. Sosiologia 33:4, 270-284.

Konttinen, Esa \& Tapio Litmanen (1996). Ympäristönhallinnan paikallinen eriaikaisuus. Teoksessa Esa Konttinen \& Tapio Litmanen (toim.): Ekokuntia ja ökykuntia. Tutkimuksia ympäristönhallinnan paikallisesta eriaikaisuudesta. Jyväskylän yliopisto, yhteiskuntatieteiden, valtio-opin ja filosofian julkaisuja 6 .

Kortelainen, Jarmo (1996). Tehdasyhdyskunta talouden ja ympäristötietoisuuden murrosvaiheessa. Joensuun yliopiston yhteiskuntatieteellisiä julkaisuja 24.

Kuusi, Matti (1965). Pohjoiset reservit. Epätieteellisiä puheenvuoroja. Kirjayhtymä, Helsinki Moilanen, P. (1991). Varkauden teollisuus 175 vuotta. Varkauden museon julkaisuja IV. Pieksämäki.

Pitkänen, Mia (1998). Ympäristökysymysten julkisuus teollisuuspaikkakunnalla. Warkauden 
Kortelainen, Jarmo (1996). Tehdasyhdyskunta talouden ja ympäristötietoisuuden murrosvaiheessa. Joensuun yliopiston yhteiskuntatieteellisiä julkaisuja 24 .

Kuusi, Matti (1965). Pohjoiset reservit. Epätieteellisiä puheenvuoroja. Kirjayhtymä, Helsinki

Moilanen, P. (1991). Varkauden teollisuus 175 vuotta. Varkauden museon julkaisuja IV.

Pieksämäki.

Pitkänen, Mia (1998). Ympäristökysymysten julkisuus teollisuuspaikkakunnalla. Warkauden Lehti paikallisten ympäristökysymysten ja elämäntapojen ympäristösuhteen ilmentäjänä ja määrittäjänä 1970-luvulta nykypäivään. Alue ja Ympäristö, 27:1, 65-78.

Roos, J.P. (1987). Suomalainen elämä. Tutkimus tavallisten suomalaisten elämänkerroista. SKS,Helsinki.

Schybergson, Per (1988). Tätort kring ett företag. Historisk Tidskrift för Finland 1988, 40 - 57.

Soikkanen, H. (1963). Varkauden historia. Varkauden kaupunki. Pieksämäki.

Jarmo Kortelainen, Ytt

Maantieteen laitos

Joensuun yliopisto

jarmo.kortelainen@joensuu.fi 